\title{
MODEL PEMBELAJARAN MENULIS DENGAN PENDEKATAN PROSES-GENRE BERBASIS KEARIFAN LOKAL
}

\author{
Helaluddin \\ UIN Sultan Maulana Hasanuddin Banten, Indonesia \\ helaluddin@uinbanten.ac.id
}

\begin{abstract}
Abstrak
Menulis merupakan salah satu keterampilan berbahasa yang bersifat produktif yang memiliki tingkat kesulitan yang tinggi bagi mahasiswa. Untuk alasan itulah, pengajar diharapkan mampu menyajikan pembelajaran menulis yang dapat merangsang minat dan bakat mereka terhadap aktivitas menulis, khususnya dalam menulis akademik. Salah satu pendekatan yang dapat digunakan oleh pengajar adalah pendekatan proses genre yang merupakan pendekatan gabungan antara pendekatan proses dan genre yang telah dinyatakan sebagai pendekatan terbaik oleh para pakar bahasa. Artikel ini mengulas tentang desain model pembelajaran menulis dengan menggunakan pendekatan tersebut dengan menonjolkan aspek kearifan lokal sebagai salah satu upaya dalam memperkenalkan dan mempertahankan budaya sekitar bagi mahasiswa. Desain model pembelajaran ini memiliki empat sintaks (langkah-langkah pembelajaran), yaitu: (1) mengenali bentuk teks, (2) menganalisis struktur teks, (3) mendiskusikan isi teks, (4) menulis tekas secara mandiri, (5) menyempurnakan teks, dan (6) memublikasikan teks.
\end{abstract}

Kata kunci: model pembelajaran, menulis, pendekatan proses genre, kearifan lokal

\section{PENDAHULUAN}

Salah satu keterampilan berbahasa yang harus dikuasai mahasiswa secara baik adalah menulis. Pada konteks pendidikan tinggi, jenis keterampilan menulis yang lebih diprioritaskan adalah menulis akademik. Menulis akademik berbeda dengan jenis menulis populer ataupun sastra. Ada beberapa aturan-aturan yang membatasi dalam jenis menulis ini. Pada beberapa referensi, istilah menulis akademik disamakan artinya dengan menulis ilmiah yang menjadi keterampilan vital yang harus dikuasai oleh mahasiswa.

Pada faktanya, banyak mahasiswa yang mengalami kesulitan saat mereka harus menuangkan ide mereka dalam jenis menulis akademik. Kompetensi menulis dapat dikatakan sebagai kompetensi yang sangat kompleks dan rumit. Di samping membutuhkan penguasaan kosa kata yang bervariatif, keterampilan ini juga membutuhkan perpaduan dari tiga 
keterampilan berbahasa lainnya, baik keterampilan membaca, menyimak, dan berbicara (Babalola \& Litinin, 2012). Kompetensi ini terdiri dari dua aktivitas utama, yaitu aktivitas yang menekankan pada unsur bahasa dan unsur gagasan (Kuswandari et al., 2018).

Kompleksitas aktivitas menulis tidak dapat dilepaskan dari kemampuan seseorang untuk menuangkan ide ke dalam bentuk rangkaian kata-kata dengan struktur dan tata bahasa yang baik dan benar. Brown menjabarkan bahwa menulis merupakan proses yang dilewati melalui berbagai aktivitas, seperti aktivitas dalam pemikiran, penyusunan draf tulisan, hingga aktivitas dalam memperbaiki tulisan tersebut (Aunurrahman dkk., 2016).

Jika ditinjau dari sasaran yang hendak dicapai, pembelajaran menulis masih difokuskan pada tataran deklaratif atau taraf pembelajaran yang berkutat tentang pengetahuan (tentang apa menulis) dan taraf pengetahuan prosedural atau mengetahui bagaimana menulis (Tao dikutip Yanti, Suhartono, \& Hiasa, 2018). Dengan kata lain, pembelajaran menulis saat ini belum menyentuh tataran lain yang lebih penting peranannya, yaitu tataran kontekstual. Tataran ini mengajarkan kepada mahasiwa tentang kapan dan bagaimana menulis tersebut dilakukan.

$\begin{array}{ccc}\text { Pemicu } & \text { lain } & \text { yang } \\ \text { menyebabkan } & \text { kurangnya } & \text { minat } \\ \text { menulis bagi } & \text { mahasiswa } & \text { adalah }\end{array}$
kekeliruan sebagian dosen yang menerapkan model pembelajaran dengan menitikberatkan pada aspek kesalahan-kesalahan berbahasa saja. Para dosen cenderung mengabaikan aspek wacana komunikasi pada kegiatan menulis mahasiswa. Bahkan, ada dosen yang memberikan skor minim bagi mahasiswa yang memiliki banyak kesalahan pada aspek tata bahasa meskipun memiliki ide dan gagasan yang menarik (Lap \& Truc, 2014). Senada dengan pernyataan tersebut, Ghina (2016) menguraikan bahwa pada praktik pembelajaran menulis banyak dosen yang tidak memberikan prioritas yang setara terhadap unsur konten, tujuan, dan bentuk teks yang menyebabkan sedikit mahasiswa 
dapat menulis dengan tujuan dan karakter yang baik.

Berkaitan dengan penggunaan metode pembelajaran, banyak dosen menggunakan metode pembelajaran yang kurang sesuai. Sebagian dosen hanya memberikan tugas menulis secara bebas namun tidak mengajarkan kepada mahasiswa bagaimana aktivitas menulis tersebut seharusnya dilakukan (Ghina, 2016). Fakta tidak jauh berbeda juga dikemukakan oleh Adnyana, Putra, \& Suryaniadi (2017) yang mengungkapkan bahwa langkahlangkah pembelajaran menulis selama ini cenderung sederhana yang dimulai dengan pemberian materi, latihan atau penugasan, dan dilanjutkan dengan presentasi tulisannya.

Pendekatan proses-genre merupakan pendekatan yang menggabungkan antara pendekatan produk, pendekatan proses, dan pendekatan genre. Secara ringkas, Badger \& White (2000) menguraikan bahwa pendekatan proses-genre memuat berbagai aspek berikut: (1) pengetahuan tentang bahasa (dengan input mahasiswa seperti pada pendekatan berbasis produk), (2) pengetahuan tentang konteks (khususnya tujuan menulis seperti pada pendekatan genre), dan (3) keterampilan dalam menggunakan bahasa (memanfaatkan potensi mahasiswa seperti dalam pendekatan proses).

Salah satu keunggulan pendekatan proses-genre adalah terbentuknya kebiasaan mahasiswa dalam aktivitas menulis dengan beberapa aspek, yaitu esensi penulisan seperti bentuk dan konten, ide dan pengorganisasian, sintaksis \& makna, menulis, dan merevisi (Xu $\&$ Xuemei, 2018). Dengan demikian, pendekatan ini memungkinkan bagi mahasiswa untuk mempelajari antara tujuan dan bentuk genre tertentu karena mereka menggunakan tahapan pra-menulis, menyusun, merevisi, dan mengedit (Tesfie, 2017).

\section{Kearifan Lokal}

Istilah kearifan lokal telah menjadi topik pembahasan dalam dunia pendidikan mengingat budaya luar telah bengitu dalam mempengaruhi ke semua lapisan 
masyarakat di Indonesia. Kearifan lokal merupakan semua bentuk pengetahuan, kepercayaan, pemahaman, dan wawasan sertaadatistiadat atau etika yang menjadi pedoman bagi perilaku manusia dalam kehidupan dalam komunitas ekologis(Laksono et al., 2018). Selain itu, kearifan lokal diartikan sebagai kecerdasan manusia yang dimiliki oleh kelompok tertentu yang berasal dari pengalaman masyarakat itu sendiri(Rahyono, 2015). Dengan kata lain, kearifan lokal merupakan hasil karya masyarakat tertentu melalui pengalamannya dan bahkan mungkin tidak dialami oleh masyarakat lain.

Kearifan lokal juga dimaknai sebagai bentuk pengetahuan lokal yang telah terintegrasi dengan sistem kepercayaan, norma, dan budaya pada suatu daerah tertentu(Murwaningsih et al., 2020). Bahkan, kearifan lokal tersebut juga diekspresikan dalam tradisi dan mitos yang dianut oleh masyarakat sekitar sejak lama(Muharom\& Madkur, 2018). Selain itu, definisi senada juga dikemukan oleh para ahli yang menyebut bahwa kearifan lokal diartikan juga sebagai gagasan, nilai, pandangan lokal yang sarat dengan kearifan, nilai yang tertanam, dandiikuti oleh anggota masyarakat(Dahliani et al., 2015).

Secara etimologi, kearifan lokal terdiri dari dua kata, yaitu kearifan dan lokal. Istilah lain yang memiliki makna yang sama dengan kearifan lokal antara lain local knowledge dan local genius.Kearifan lokal dalam kedua hal tersebut dapat disebut kearifan lokal, sebagaimana dijelaskan oleh Kementerian Pendidikan dan Kebudayaan Indonesia, bahwa kearifan lokal dapat dilihat sebagai konsep pembelajaran di sekolah untuk meningkatkan potensi lokal daerah di Indonesia(Pratiwi \& Suwandi, 2021).

\section{Model Pembelajaran}

Dalam praktiknya di lapangan, para guru/dosen dan praktisi masih banyak salah kaprah dalam memaknai istilah antara model, pendekatan, strategi, metode, teknik, dan taktik pembelajaran. Padahal, keenam istilah tersebut memiliki perbedaan yang cukup mendasar. Menurut Gustafson dan Branch 
(2002) model adalah: (1) model membantu mahasiswa dan pengajar untuk merepresentasikan realitas, (2) model merupakan representasi sederhana dari sebuah kenyataan yang lebih luas dan kompleks, (3) model merupakan bentuk penyederhanaan realitas karena pada kenyataanya terlalu kompleks dan unik pada situasi tertentu, dan (4) model akan membantu dalam mengidentifikasi apa yang berlaku umum dalam beberapa konteks.

$$
\text { Istilah "model"dapat }
$$

didefinisikan dengan beberapa arti. Menurut Sagala dikutip Hasbi (2016) ada tujuh definisi tentang kata "model", yaitu: (1) suatu tipe atau desain, (2) suatu deskripsi atau analogi yang digunakan untuk membantu proses visualisasi sesuatu yang tidak dapat langsung dilihat, (3) suatu sistem yang berisi asumsi, data, dan interferensi yang digunakan untuk menggambarkan suatu objek, (4) suatu desain yang disederhanakan dari sistem kerja, (5) suatu terjemahan realitas yang disederhanakan, (6) suatu deskripsi dari suatu sistem yang mungkin bersifat imajiner, dan (7) penyajian yang diperkecil agar dapat menjelaskan dan menunjukkan sifat bentuk aslinya.

Pada dasarnya, hakikat pembelajaran adalah sebuah proses komunikasi timbal balik antara dosen dan mahasiswa dalam mencapai tujuan pembelajaran yang telah ditetapkan.Dalam mempermudah proses pembelajaran tersebut dibutuhkanlah sebuah model pembelajaran. Model yang dimaksud dalam konteks ini diartikan sebagai objek atau konsep yang digunakan dalam menyajikan sesuatu (Trianto, 2011).

Model pembelajaran merupakan suatu cara dalam membantu mahasiswa/siswa untuk memperoleh informasi, gagasan, keterampilan, nilai dan cara berpikir serta meningkatkan kemampuan belajarnya(Joyce, Weil, \& Calhoun, 2011). Senada dengan Joyce dkk., Angelina (2018) mengibaratkan model pembelajaran sebagai sebuah kerangka konseptual yang berisi beberapa tahapan dan disusun secara sistematis dalam mengintegrasikan aktivitas kelas dalam mencapai tujuan. 
Model pembelajaran adalah rencana yang dapat digunakan untuk membentuk program dalam merancang bahan ajar dan membimbing proses instruksional (Pateliya, 2013). Di sisi lain, model pembelajaran dimaknai juga sebagai sebuah pola atau kerangka konseptual yang menggambarkan berbagai instrumen dan prosedur pengelolaan pembelajaran secara sistematis (Said, 2014). Model pembelajaran tersebut digunakan sebagai standar dan acuan untuk merencanakan pembelajaran, melaksanakan pembelajaran, menilai hasi belajar, dan mengembangkan sistem pembelajaran lebih lanjut.

Di samping itu, model pembelajaran dapat diasosiasikan sebagai sebuah strategi yang disandarkan pada teori (atau hasil dari penelitian) baik dari pendidik, psikolog, filsuf, dan lain-lain yang menggambarkan bagaimana suatu proses didesain untuk pembelajaran (Ellis, 1979). Lebih lanjut, Ellis menyebut bahwa setiap model pembelajaran yang berisi tentang: (1) rasional, (2) serangkaian langkahlangkah yang digunakan oleh dosen dan mahasiswa, (3) deskripsi sistem pendukung yang sesuai, dan (4) metode evaluasi terhadap progres mahasiswa.

Dalam sebuah model pembelajaran terdiri atas lima unsur utama yang membangunnya (Joyce, Weil, \& Emily Calhoun, 2011). Unsur-unsur yang dimaksud adalah: (1) syntax yaitu langkah-langkah operasional pembelajaran, socialsystem, adalah suasana dan norma yang berlaku dalam pembelajaran, principlesofreaction, menggambarkan bagaimana seharusnya guru mendorong dan merespon siswa,

supportsystemadalah segala sarana, bahan, atau lingkungan belajar yang mendukung pembelajaran, dan (5) instructionaldan nurturanteffects hasil belajar yang diperoleh langsung berdasarkan tujuan yang ingin dicapai dan hasil dampak pengiring (nurturanteffects).

\section{Keterampilan Menulis}

Sebelum mengulas tentang definisi menulis akademik, ada baiknya bagian ini dimulai dengan 
membedakan antara dunia akademik dan dunia nyata (realworld and academic world). Kedua dunia tersebut sangat berbeda dan tidak dapat disamakan. Menurut Pomfrett, Dank, \& McClay (2013) dunia nyata merupakan tempat orang-orang mengalami dan merasakan pengalaman hidupnya seperti bekerja, bermain dan berolahraga, menonton, dan lain-lain. Di sisi yang lain, dunia akademik adalah dunia yang diisi dengan teori, penjelasan, ide, dan berbagai kritik. Dengan demikian, kita tidak dapat mengalami dunia akademik seperti saat mengalami pada dunia nyata. Di dunia akademik, kita belajar dari tangan kedua, yaitu dari apa yang ditulis oleh orang lain dan bukan dari pengalaman kita sendiri.

Berdasarkan namanya, menulis akademik tentu saja berkaitan dengan aktivitas menulis yang dilakukan dalam lingkungan akademik. Ada beberapa kriteria yang digunakan dalam mengklasifikasikan jenis tulisan menjadi kelompok tulisan akademik. Zainurrahman (2011) menguraikan beberapa kriteria tulisan akdemik, yaitu: (1) tulisan akademik itu ditulis oleh komponen masyarakat akademik, (2) bersifat ilmiah, dan (3) bersifat konvensional atau dikekang dengan berbagai aturan. Di samping keempat kriteria tersebut, ada kriteria lain yang digunakan dalam mengkategorikan sebuah tulisan akademik, yaitu mengandung definisi, deskripsi, klasifikasi, kausalitas, perbandingan, kontras, dan argumen (Murray \& Hughes, 2008).

Di sisi lain, menulis akademik diartikan sebagai hasil atau produk dari perpaduan beberapa aspek. Aspek-aspek yang dimaksud adalah pembaca atau audiens, tujuan, pengorganisasian, gaya, alur, dan presentasi (Swales \& John dikutip Yanti dkk. (2018). Lebih lanjut, mereka juga menegaskan bahwa menulis akademik merupakan karya tulis yang menggunakan kaidahkaidah atau aturan-aturan tertentu yang telah disepakati dalam suatu komunitas akademik.

Karakteristik menulis akademik dapat diidentifikasi dengan beberapa hal, yaitu: (1) dalam proses menulis harus memfokuskan pada 
peran penting dalam kaitannya dengan komunitas (community), (2) penulis harus peduli dengan kualitas tulisannya, dan (3) komunitas harus membantu penulis dengan mengakses sumber-sumber dan menemukan petunjuk dan dukungan (Yugianingrum, 2010). Senada dengan pernyataan tersebut, karakteristik lain dalam menulis akademik diutarakan oleh Aunurrahman dkk. (2017) yang mencakup aspek kompleksitas, formalitas, objektivitas, dan keterikatan (hedging).

Selanjutnya, jenis tulisan atau teks akademik dapat pula diidentifikasi dari aspek bahasa yang digunakannya. Menurut Abidin, Misbah, Putra, \& Ertinawati(2019) ada beberapa ciri bahasa dalam tulisan akademik yang mencakup: (1) bahasa yang digunakan adalah bahasa yang taat asas baik dalam aspek teknis penulisan, pilihan kata atau diksi, susunan kalimat, paragraf, dan unsur maknanya, (2) titik pandang kebahasaan yang taat asas baik dalam ragam dan modus maupun mengenai kata diri dan kata ganti, (3) istilah yang digunakan merupakan istilah-istilah keilmuan, (4) menghindari penggunaan bahasa yang sudah usang, kolot, dan basi, (5) menghindari bahasa yang ekstrim, berlebihan, dan mengharu biru, (6) bahasa yang digunakan harus menekankan pada aspek komunikasi dengan pikiran tanpa melibatkan perasaan, (7) mengurangi penggunaan kata kiasan, dan, (8) kalimat dan paragraf dalam karya tulis akademik sebaiknya pada cakupan sedang (tidak terlalu panjang atau singkat).

\section{Pendekatan Proses Genre}

Jenis pendekatan integratif selain pendekatan proses produk adalah pendekatan proses genre atau process genre approach. Pendekatan ini diartikan sebagai sebuah aktivitas menulis yang merupakan perpaduan antara pendekatan proses dan genre. Pendekatan ini hadir dengan mengadopsi model proses dan teori genre yang ditujukan sebagai langkah solutif dari berbagai keterbatasan dalam kedua pendekatan tersebut (Babalola \& Litinin, 2012). Artinya, perpaduan kedua pendekatan tersebut akan 
saling melengkapi kekurangankekurangan antara pendekatan satu dengan yang lain (Agibuay, 2017).

Pendekatan proses-genre mengindikasikan bahwa menulis tidak hanya mengutamakan pemikiran kreatif dan bagaimana tindakan penulis dalam membentuk teks tetapi juga mengutamakan pengetahuan fitur linguistik serta komunitas wacana tertentu tentang genre tersebut dibuat (Gao, 2007). Selanjutnya, Yanghee \& Jiyoung(2005) menyatakan bahwa pendekatan proses genre sebagai pelibatan pengetahuan tentang bahasa, konteks, dan tujuan penulisan terjadi serta keterampilan dalam menggunakan bahasa. Pendekatan ini memungkinkan mahasiswa untuk mempelajari hubungan antara tujuan dan bentuk genre tertentu karena menggunakan tahapan pra-menulis, menyusun, merevisi, dan mengedit (Tesfie, 2017).

Dalam pendekatan proses genre, fokus utamanya adalah aktivitas menulis yang diatur dengan pendekatan proses-genre dalam situasi sosial. Dengan kata lain, teks yang dicipatakan penulis selalu memiliki tujuan berdasarkan situasi dan kondisi tertentu (Azhar et al., 2016). Dalam pendekatan proses genre, para praktisi dan peneliti menemukan lebih banyak manfaat dan kelebihannya dibandingkan dengan kekurangannya. Secara khusus, tahapan dalam pendekatan ini bersifat sangat fleksibel karena mencakup pada pengetahuan bahasa (pendekatan produk dan genre), konteks dan tujuan penulisan (pendekatan genre), dan kemampuan yang dibutuhkan dalam penggunaan bahasa (pendekatan proses)(Pramila, 2017).

Pendekatan proses-genre digunakan dengan tujuan untuk membiasakan mahasiswa dengan tujaun dan esensi dari aktivitas menulis. Artinya, pendekatan ini memfokuskan beberapa aspek dalam aktivitas menulis, antara lain bentuk dan konten, gagasan dan cara penyajian teks, sintaks dan makna, serta aktivitas menulis \& merevisi (Xu \& Xuemei, 2018). Pendekatan proses-genre ini juga dapat membantu mahasiswa untuk mengembangkan kemampuan 
mereka pada semua tahapan proses penulisan yang berhubungan dengan tujuan dan pembaca, menawarkan kesempatan untuk mengikuti langkah-langkah penulisan dalam menganalisis teks sebagai panduan bagi tulisan mereka, dan menyusun tulisan sesuai dengan tujuan komunikasi yang nyata (Arteagalara, 2018).Yanghee \& Jiyoung (2005) mengklarifikasi ada empat prinsip dalam pendekatan ini, yaitu: (1) keseimbangan antara bentuk dan fungsi, (2) struktur bahasa dan pembelajaran, (3) memperluas kurikulum menulis, dan (4) menyediakan respons yang bermakna dan penilaian formatif.

\section{Sintaks Pembelajaran Menulis}

Hal utama dalam sebuah pembelajaran di kelas/ruang virtual adalah langkah-langkah pembelajaran atau yang biasa disebut dengan sintaks. Dalam teori pembelajaran, sintaks merupakan salah satu komponen di dalamnya selain sistem sosial, prinsip reaksi, sistem pendukung, dan dampak instruksional \& dampak pengiring. Dengan adanya sintaks, guru dapat dengan mudah melaksanakan proses pembelajaran karena urutan kegiatannya telah didesain secara sistematis. Adapun sintaks dalam pembelajaran menulis dengan mengaplikasikan konten kearifan lokal tersebut adalah:

\section{1) Mengenali Bentuk Teks}

Sintaks pertama dalam model pembelajaran ini adalah mengenali bentuk teks. Seperti halnya dalam pembelajaran menulis dengan pendekatan konvensional, biasanya siswa diperkenalkan dengan bentuk teks pada awal pembelajaran. Sebelum guru menjelaskan definisi sebuah teks, terlebih dahulu menampilkan sebuah contoh teks kepada siswa. Sebagai contoh, guru menampilkan contoh teks berupa esai argumentatif melalui buku ajar atau dari internet. Jika memungkin, guru dapat juga menampilkan jenis esai lain untuk dijadikan sebagai materi pembanding sehingga siswa dapat dengan mudah mengenali bentuk esai tersebut.

Berkaitan dengan aspek kearifan lokal, guru dapat memilih contoh esai yang bertemakan tentang 
budaya, bahasa, maupun jenis-jenis kearifan lokal lainnya. Jika guru tidak menemukan contoh esai yang sesuai dengan kearigan lokal setempat, maka ia dapat menulis sendiri contoh esai tersebut. Dengan demikian, selain mendapat pengetahuan tentang esai tersebut siswa-siswa juga memperoleh pengetahuan tentang salah satu bentuk kearifan lokal yang disajikan dalam esai tersebut.

\section{2) Menganalisis Struktur Teks}

Setelah siswa mengnali bentuk maupun jenis-jenis teks, guru melanjutkan ke sintaks berikutnya, yaitu menganalisis struktur teks. Pada materi menulis esai, guru menguraikan secara sistematis bagian-bagian utama dalam teks tersebut. Pada contoh esai, guru menjabarkan tiga bagian utama esai tersebut, yaitu paragraf pembuka, tubuh esai, dan paragraf penutup. Selanjutnya, guru mengulas secara lebih spesifik ke tiap-tiap bagian secara lebih detail. Pada bagian paragraf pembuka, guru dapat menjelaskan dan menjabarkan ciriciri dari pernyataan tesis agar siswa mampu mengindentifikasinya pada contoh esai lainnya.

\section{3) Mendiskusikan Teks}

Pada sintaks ketiga ini, guru dapat mengeksplorasi konten tentang kearifan lokal yang diusung dalam esai tersebut. Guru meminta siswaa untuk berdiskusi dengan membentuk kelompok yang terdiri dari 3 sampe 4 siswa dalam satu kelompok. Selanjutnya, siswa diminta untuk memberikan komentar, kritik, dan saran tentang tema esai tersebut. Diskusi menjadi metode yang paling tepat dalam aktivitas brainstorming agar siswa dapat saling bertukar ide, gagasan, dan pandangan tentang kearifan local tersebut.

\section{4) Menulis Teks secara Mandiri}

Langkah pembelajaran berikutnya adalah menulis esai secara mandiri. Pada fase ini, guru menginstruksikan siswa untuk menyusun kerangka tulisan terlebih dahulu. Siswa dapat mengonsultasikan kerangka tulisan mereka kepada guru untuk dapat menyempurnakan ide-ide yang akan ditulisnya. Setelah guru memberikan 
saran dan masukan, siswa melanjutkan aktivitasnya dengan menulis esai secara penuh. Selain berdiskusi dengan guru, pada fase ini juga siswa dapat berdiskusi dengan teman-teman sekelasnya agar mereka mendapat gambaran dan masukan yang lebih luas dan komprehensif.

\section{5) Menyempurnakan Teks}

Pada sintaks ke-5, siswa diarahkan untuk melakukan aktivitas evaluasi terhadap teks esai yang telah ditulisnya. Tahap penyempurnaan teks difokuskan pada aspek kebahasaan seperti struktur kalimat, penggunaan pilihan kata atau diksi, penggunaan kata baku dan tidak baku, penggunaan istilah, dan lainlain. Guru juga dapat merekomendasikan penggunaan kamus Bahasa Indonesia Daring dalam memudahkan siswa melakukan kroscek terhadap tulisannya.

\section{6) Memublikasikan Teks}

Langkah terakhir dalam model pembelajaran ini adalah memublikasikan teks. Dalam pembelajaran konvensional selama ini, tahap ini jarang dilakukan oleh guru dan siswa. Aktivitas publikasi dapat dilakukan melalui beberap platform yang sesuai, mulai dari media sosial dan blog pribadi hingga media publikasi lainnya. Bentuk teks berupa paragraf dapat dipublikasikan melalui media blog atau media sosial pribadi siswa yang bersangkutan, seperti Facebook dan Instagram. Untuk jenis tulisan yang bersifat populer dan ilmiah, guru dapat mengarahkan siswa untuk memublikasikannya melalui laman researchgate, osf-preprints, dan lainlain.

\section{SIMPULAN}

Menulis merupakan salah satu keterampilan berbahasa yang memiliki tingkat kesulitan yang tinggi. Hal ini dapat dimaklumi karena menulis membutuhkan beberapa kemampuan yang harus dipadukan dalam satu aktivitas, antara lain kemampuan menggunakan bahasa, kemampuan mengaktualisasikan ide dan pikiran ke dalam bentuk tulisan, dan lainlain. Untuk itulah, perlu penggunaan metode pembelajaran yang tepat agar 
kemampuan mahasiswa dapat dikembangkan, yaitu dengan pendekatan proses genre. Selain itu, proses pembelajaran juga perlu melibatkan aspek lain yag turut mendukung kemampuan mahasiswa di masa sekarang dan akan datang. Salah satunya adalah aspek kearifan lokal yang memang harus dikenalkan secara mendalam. Untuk itulah, seorang pengajar harus mampu mendesain pembelajaran menulis dengan pendekatan proses-genre. Pembelajaran ini didesain dengan menerapkan beberapa langkah, yaitu:

(1) mengenali bentuk teks, (2) menganalisis struktur teks, (3) mendiskusikan contoh teks, (4) menulis teks secara mandiri, (5) menyempurnakan teks, dan (6) memublikasikan teks. Tahapantahapan tersebut dikembangkan dengan tujuan untuk membantu mahasiswa mengembangkan keterampilan menulis dengan menguasai beberapa aspek, yaitu product-oriented, process-oriented, dan genre-oriented.

\section{DAFTAR PUSTAKA}

Abidin, Y., Misbah, B. F. J. M., Putra, A. W., \& Ertinawati, Y.
(2019). Kemahiran Berbahasa Indonesia untuk Perguruan Tinggi. Bumi Aksara.

Adnyana, I. B. A., Putra, K. D. C., \& Suryaniadi, S. M. (2017). Peningkatan Keterampilan Menulis Akademik Berbasis Metode Quantum Pada Pendidikan S-1 Terapan Politeknik Negeri Bali. Soshum: Jurnal Sosial dan Humaniora, 7(1), 61-78.

Agibuay, R. M. (2017). Descriptive Writing Using The Processgenre Approach. Asia Pasific Journal of Contemporary Education and Communication Technology, 3(1).

Angelina, P. (2018). Developing Task-based Learning Model for Language Teaching Media Course in English Language Education Study Program. Language and Language Teaching Journal (LLT), 21(1), 36-45.

Arteaga-lara, H. M. (2018). Using The Process-genre Approach to Improve Fourth-grade EFL Learners' Paragraph Writing. Latin American Journal of Content and Language Integrated Learning, 10(2), 217-244.

https://doi.org/10.5294/laclil.20 17.10.2.3

Aunurrahman, Hamied, F. A., \& Emilia, E. (2016). Exploring An Academic Writing Class in An Indonesian University Context. Language Circle: Journal of Language and Literature, 11(1), 1-12.

Aunurrahman, Hamied, F. A., \& Emilia, E. (2017). Exploring The Tertiary EFL Students' 
Academic

Writing

Competences. Indonesian

Journal of Applied Linguistics, 7(1), 72-79.

Azhar, M. A., Kiran, S., \& Khan, T. (2016). Teaching Writing Skill Based on Process Genre Approach in Community Learning Context. Proceedings of SOCIONT 2016 3rd International Conference on Education, Social Science and Humanities, May, 412-417.

Babalola, \& Litinin, H. A. (2012). Effects of Process-genre Based Approach on the Written English Performance of Computer Science Students in A Nigerian Polytechnic. Journal of Education and Practice, 3(6), 1-7.

Badger, R., \& White, G. (2000). A Process Genre Approach to Teaching Writing. ELT Journal, 54(2), 153-160. https://doi.org/10.1093/elt/54.2. 153

Dahliani, D., Soemarno, I.,\& Setijanti, P. (2015). Local Wisdom in Built Environment in Globalization Era. International Journal of Education and Research, 3(6), 157-166.

Ellis, S. S. (1979). Model of Teaching: A Solution to the Teaching Style/Learning Style Dillema. The Association for Supervision and Curriculum.

Gao, Y. (2007). Teaching Writing in Chinese University: Finding An Eclectic Approach. Asian EFL Journal of English Language Teaching and Research Article.

Ghina, F. (2016). Application of The Process Genre Approach for
Improving Writing. English Education Journal, 7(4), 481495.

Hasbi, H. (2016). Pengembangan Model Pembelajaran Berbasis Masalah Menggunakan Lingkungan Sekitar untuk Meningkatkan Ketuntasan Belajar di Sekolah Dasar.

Joyce, B., Weil, M., \& Emily Calhoun. (2011). Models of Teaching (Delapan). Pustaka Pelajar.

Kuswandari, A. H., Slamet, S. Y., \& Setiawan, B. (2018). Kontribusi Kemampuan Berpikir Kritis sebagai Konstruksi Peningkatan Keterampilan Menulis Esai. Gramatika: Jurnal Penelitian Pendidikan Bahasa dan Sastra Indonesia, 4(1). https://doi.org/10.22202/jg.2018 .v4i1.2410

Laksono, B. A., Supriyono, S., \& Wahyuni, S. (2018). An Investigation of Local Wisdom to Support Adult Literacy Program. PEOPLE: International Journal of Social Sciences, 4(2), 1320-1336. https://doi.org/10.20319/pijss.20 18.42.13201336

Lap, T. Q., \& Truc, N. T. (2014). Enhancing Vietnamese Learners' Ability in Writing Argumentative Essays. Journal of Asia TEFL, 11(2), 63-91.

Muharom A., A., \& Madkur, A. (2018). Think globally, Act Locally: The Strategy of Incorporating Local Wisdom in Foreign Language Teaching in Indonesia. International Journal of Applied Linguistics and English Literature, 7(2), 1-8. https://doi.org/10.7575/aiac.ijale 
1.v.7n.2p. 1

Murray, N., \& Hughes, G. (2008). Writing Up Your Universsity Assigment and Research Project. McGraw Hills.

Murwaningsih, T., Fadhilah, S. S., \& Sholeh, A. R. (2020). The Implementation of characters' Values through Local Wisdom of Sadranan in Elementary Schools. International Journal of Multicultural and Multireligious Understanding, 7(1), 450-458. https://doi.org/http://dx.doi.org/ 10.18415/ijmmu.v7i1.1315

Pateliya, Y. P. (2013). An Introduction to Modern Models of Teaching. International Journal for Research in Education, 2(2), 125-129.

Pomfrett, J., Dank, D., \& McClay, D. (2013). Academic Essay Writing. Charles Darwin University.

https://doi.org/10.1108/EUM00 00000001008

Pramila, N. (2017). Approaches to Teaching English Writing: A Research Note. Studies in Foreign Language Education, 39, 141-148.

Pratiwi, V. U., \& Suwandi, S. (2021). Local Wisdom in The Picture Storybook for Elementary School Students in Sukoharjo Regency. Budapest International Research and Critics Institute (BIRCIJournal): Humanities and Social Sciences, 4(1), 12621271.

https://doi.org/10.33258/birci.v4 i1.1751

Rahyono, F. X. (2015). Kearifan Budaya dalam Kata. Wedatama
Widya sastra.

Said, H. (2014). Pengembangan Model Pembelajaran Virtual untuk Meningkatkan Efektivitas Pembelajaran pada Madrasah Negeri di Kota Parepare. Lentera Pendidikan, 17(1), 1833.

Tesfie, A. (2017). Teachers' Cognition on Process Genre Approach and Practice of Teaching Writing Skills in EFL Context. English for Spesific Purposes World, 54(19).

Trianto, T. (2011). Model-model Pembelajaran Inovatif Berorientasi Konstruktivistik: Konsep, Landasan Teoretis Praktis, dan Implementasinya. Prestasi Pustaka.

Xu, X., \& Xuemei, L. (2018). Teaching Academic Writing through a Process-genre Approach: A Pedagogical Exploration of an EAP Program in China. The Electronic Journal for English as a Second Language, 22(2), 1-21.

Yanghee, K., \& Jiyoung, K. (2005). Teaching Korean University Writing Class: Balancing the Process and Genre Approach. Asian EFL Journal, 7(2), 1-15. http://asian-efljournal.com/1280/quarterlyjournal/2005/06/teachingkorean-university-writing-classbalancing-the-process-and-thegenre-approach/

Yanti, N., Suhartono, S., \& Hiasa, F. (2018). Keterampilan Menulis Akademik Mahasiswa S-1 Program Studi Pendidikan Bahasa dan Sastra Indonesia FKIP Universitas Bengkulu. Silampari Bisa: Jurnal 
Penelitian Pendidikan Bahasa Indonesia, Daerah, dan Asing, l(1), 1-16. https://doi.org/10.31540/silamp aribisa.v1i1.4

Yugianingrum. (2010). Producing an
English Academic Paper:

Process, Problems and

Solutions. US-China Foreign Language, 8(1), 39-49.

Zainurrahman. (2011). Menulis: dari

Teori hingga Praktik. Alfabeta. 